\title{
SISTEM FINANSIAL PENDIDIKAN DI INDONESIA (ANALISIS TENTANG SIGNIFIKANSINYA TERHADAP PENGELOLAAN HUMAN CAPITAL)
}

\author{
Aminuddin, Ahmad Sukri Harahap, M. Nuh Dawi \\ Universitas Nahdlatul Ulama Sumatera Utara, Sekolah Tinggi Agama Islam Serdang Lubuk Pakam, \\ Sekolah Tinggi Agama Islam Sumatera Medan \\ Jl. Gaperta Ujung No.2, Tj. Gusta, Kota Medan, Sumatera Utara \\ e-mail: aminuddin8607@gmail.com, sukriharahap99@gmail.com, awisaragih@gmail.com
}

\begin{abstract}
Abstrak: Penelitian ini bertujuan untuk menganalisis sistem finansial pendidikan di Indonesia, yang fokus permasalahanya pada pengelolaan Human Capital. Metode penelitian yang digunakan dalam penelitian ini adalah Library Research, dengan teknik pengumpulan data dokumentasi, sedangkan analisis data menggunakan teknik analisis konten. Hasil penelitian menjelaskan bahwa Pendidikan sangat berpengaruh kepada ekonomi suatu bangsa. Pendidikan bukan hanya dapat menjadikan manusia yang berpengetahuan, berpendidikan, dan mengetahui teknologi saja, namun pendidikan dapat dijadikan sarana sebagai penunjang pertumbuhan ekonomi. Karena dengan pendidikan manusia membuat inovasi-inovasi baru yang menunjang ekonomi sesuai dengan perkembangan zaman. Pendidikan sebagai human capital atau human investasi adalah karena Pendidikan merupakan investasi yang paling penting dalam modal manusia untuk menjawab tantangan global pada saat ini. Pendidikan menjadi salah satu komponen vital dalam pertumbuhan dan perkembangan suatu negara. Peran ganda pendidikan, yaitu sebagai input dan output, membuat pendidikan sangat penting dalam pembangunan ekonomi. Pendidikan di negara berkembang berperan untuk membentuk sebuah kemampuan negara dalam menyerap teknologi modern dan mengembangkan kapasitas agar tercipta pertumbuhan dan pembangunan yang berkelanjutan
\end{abstract}

Kata Kunci: Finansial Pendidikan, Anggaran Pembiayaan, Human Kapital

\begin{abstract}
This study aims to analyze the financial system of education in Indonesia, which focuses on the management of Human Capital. The research method used in this study is Library Research, with documentation data collection techniques, while data analysis uses content analysis techniques. The results of the study explain that education is very influential on the economy of a nation. Education can not only make people who are knowledgeable, educated, and know technology, but education can be used as a means to support economic growth. Because with education, humans make new innovations that support the economy in accordance with the times. Education as human capital or human investment is because education is the most important investment in human capital to answer today's global challenges. Education is a vital component in the growth and development of a country. The dual role of education, namely as input and output, makes education very important in economic development. Education in developing countries plays a role in shaping the country's ability to absorb modern technology and develop capacity to create sustainable growth and development.
\end{abstract}

Keywords: Education Finance, Financing Budget, Human Capital 
Hikmah, Vol. 18, No. 2, Juli-Desember 2021, p-ISSN: 1829-8419 e-ISSN: 2720-9040

\section{PENDAHULUAN}

Investasi merupakan upaya untuk meningkatkan nilai tambah barang ataupun jasa di kemudian hari dengan mengorbankan nilai konsumsi sekarang. Investasi tidak hanya menyangkut dengan uang sebagai modal utama untuk menghasilkan keuntungan di masa depan, tetapi juga mencakup kualitas manusia yang berupa pengetahuan, keterampilan dan kecakapan yang dimiliki seseorang. Makna investasi ini memiliki arti yang relevan dengan pendidikan, karena dengan adanya pendidikan, pengetahuan, keterampilan dan kecakapan serta sikap seseorang akan semakin positif dan bertambah. Siapa saja yang berinvestasi melalui pendidikan akan merasakan atau memetik manfaatnya dikemudian hari atau di masa depan dan seseorang itu harus rela berkorban serta menunda kesenangannya atau keinginannya untuk beberapa saat sesuai dengan kondisi yang ditempuhnya. (Mesiono \& Lubis, 2021)..

Salah satu ciri Negara maju adalah tingginya tingkat pendidikan dan penguasaan teknologi, karena itu pendidikan sangat ditekankan untuk meningkatkan mutu dan kualitas sumber daya manusia seperti adanya pelatihan skill, keterampilan dan pengetahuan tentang dunia usaha agar menciptakan sumber daya manusia yang berdaya saing, kompeten, kreatif, berwawasan luas dan mempunyai integritas tinggi yang dibutuhkan oleh berbagai usaha. Pada umumnya semakin tinggi tingkat pendidikan seseorang, semakin baik pula tingkat kehidupan ekonominya. Hal ini bisa saja terjadi, sebab manusia yang lebih terdidik berkecenderungan lebih produktif dibandingkan dengan manusia-manusia yang tidak terdidik. (Akdon et al., 2015).

Pendidikan itu sendiri merupakan alat untuk mengembangkan ekonomi dan bukan sekedar menumbuhkan ekonomi. Dalam praksis manajemen pendidikan modern, salah satu dari lima fungsi pendidikan adalah fungsi teknis-ekonomis dari tataran individual sampai kepada tataran yang lebih luas. Fungsi teknis-ekonomis mengarah kepada kontribusi pendidikan untuk perkembangan ekonomi. Sebagai contoh misalnya, pendidikan dapat membantu manusia untuk memperoleh pengetahuan dan keterampilan yang dibutuhkan agar manusia dapat survive dan mampu bersaing dalam kehidupan ekonomi yang makin kompetitif. (Romadhon, 2016).

Human capital ataupun pembangunan sumber daya manusia sangat tergantung pada sistem finansial pendidikan. Pengelolaan anggaran pendidikan yang baik tentu akan meningkatkan mutu dari sumber daya manusia tersebut, Begitu juga dengan sebaliknya pengelolaan anggaran pendidikan yang kurang baik atau pun terkesan dimanipulasi atau pun di salahgunakan tentu akan memper buruk mutu sumber daya manusia. Sistem finansial pendidikan yang baik bukan hanya sekedar terlihat dari banyaknya jumlah Anggaran dana yang dikucurkan untuk pelaksanaan pendidikan. Akan tetapi financial pendidikan yang baik terlihat dari seberapa mampu pengelola pendidikan dalam mendayagunakan finansial seefektif mungkin dan seefisien mungkin.(Prayoga \& Risnandi, 2019). 
Akhir-akhir ini pengelolaan anggaran pendidikan di Negara Indonesia cukup mendapat sorotan yang Intens dari masyarakat. Tak sedikit dari para pemangku jabatan strategis di dunia pendidikan melakukan penyalahgunaan anggaran dana pendidikan. Praktek korupsi kolusi dan nepotisme di Indonesia memang masih marak terjadi, Bahkan dunia pendidikan juga menjadi salah satu sasaran segar bagi para oknum oknum yang ada dalam dunia pendidikan. Lembaga pendidikan di Indonesia memang tidak disebut sebagai lembaga profit akan tetapi disebut sebagai lembaga non profit yang artinya lembaga tersebut bergerak bukanlah dalam hal mencari keuntungan akan tetapi bergerak untuk kepentingan manusia seluas-luasnya. (Ferdi, 2013).

Untuk mendapatkan hasil optimal dari penyelenggaraan pendidikan, Maka selayaknyalah pemerintah harus mengalokasikan anggaran pembiayaan pendidikan yang sebanding dengan harapan yang dicetuskan oleh pemerintah. Artinya semakin tinggi harapan pemerintah terhadap hasil yang optimal dari penyelenggaraan pendidikan maka semakin tinggi pula mengalokasikan anggaran pembiayaan pendidikan. Dan tentunya dalam pengelolaan anggaran pendidikan haruslah dilakukan secara transparan, akuntabel dan terorganisir. Alokasi anggaran pembiayaan yang tinggi memang menjadi human investment dengan kata lain menjadi investasi untuk perkembangan peradaban manusia di masa mendatang. (Abidin, 2017).

Penelitian ini bertujuan untuk menganalisis sistem finansial pendidikan di
Indonesia tersususn relevansinya dengan pengelolaan human capital. Sehingga penelitian ini diharapkan dapat berkontribusi bagi pemerintah sebagai pengelola anggaran pendidikan pada tingkat atas, dan berkontribusi bagi penyelenggara pendidikan kepala sekolah ataupun komite sekolah.

\section{METODE PENELTIIAN}

Penelitian ini menggunakan jenis penelitian kualitatif berbasis library research atau studi kepustakaan. Sumber data dalam penelitian ini terdiri dari dua jenis sumber pustaka primer dan sumber pustaka sekunder. Adapun Sumber data primer Dalam penelitian ini adalah buku-buku yang berkaitan dengan sistem finansial pendidikan, Sedangkan sumber sekunder dalam penelitian ini adalah temuan-temuan penelitian baik dalam bentuk tugas akhir maupun dalam bentuk artikel ilmiah yang telah diterbitkan di jurnal maupun di prosiding penelitian.

$$
\text { Pengumpulan data dilakukan }
$$

menggunakan teknik dokumentasi. Teknik dokumentasi yakni pengumpulan data-data terkait dengan penelitian dari dokumendokumen penelitian seperti yang telah disebutkan pada sumber data primer maupun sumber data sekunder. Teknik analisis data menggunakan teknik analisis konten, Maksudnya teknik yang digunakan untuk menganalisis data data dokumen penelitian dengan menganalisis materi yang terkandung dalam dokumen tersebut dengan menggunakan interpretasi dari penulis.

Untuk menjamin keabsahan data Dalam hal ini peneliti menggunakan teknik Keterandalan data. Data yang digunakan 
dalam penelitian ini benar-benar dipastikan berasal dari sumber-sumber yang memang relevan dengan penelitian ini. Bahkan dapat dipastikan bahwa sumber-sumber yang menjadi dasar dalam pengambilan keputusan terhadap data penelitian ini tidaklah berasal dari sumber kedua ataupun sumber ketiga melainkan pada sumber bagian yang pertama. Untuk lebih jelasnya bagan alur penelitian akan disajikan sebagaimana gambar berikut ini.

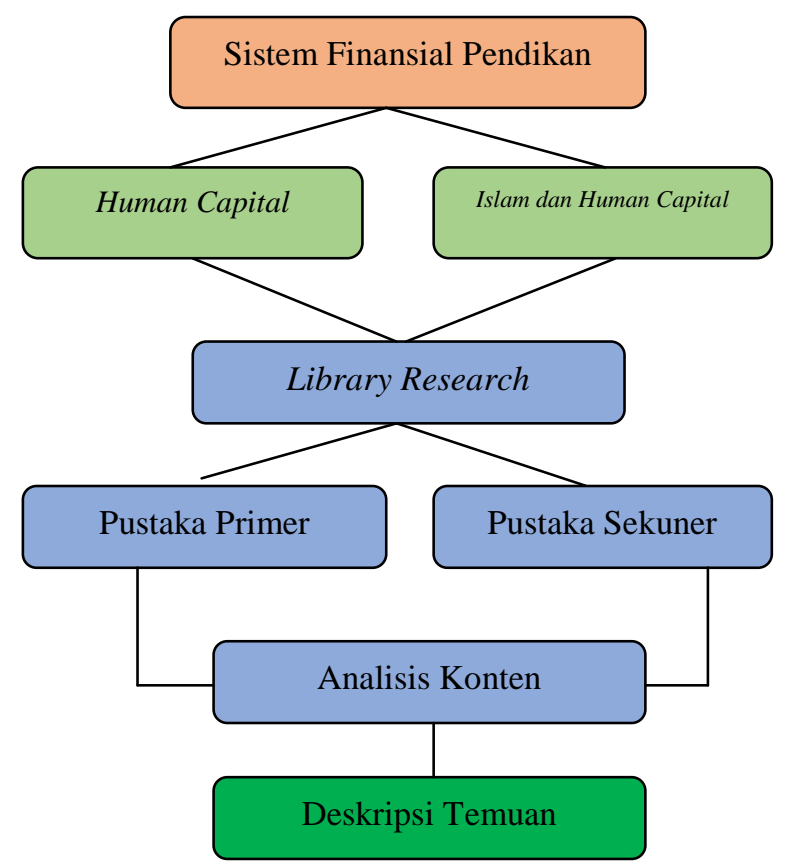

Gambar 1. Bagan Alur Penelitian

\section{HASIL DAN PEMBAHASAN}

Pembahasan penelitian akan disesuaikan dengan tujuan penelitian yakni perkembangan pendidikan sebagai human capital, pengelolaan pendidikan sebagai human capital di Indonesia, dan Pandangan Islam Terhadap Human Capital. Namun sebelum membahasnya lebih detail, terlebih dahulu akan dikemukakan secara umum sebagai pengantar pembahasan yakni pendidikan sebagai human capital.
Modal manusia atau human capital merupakan istilah yang sering digunakan oleh para ekonom untuk pendidikan, kesehatan, dan kapasitas manusia yang dapat meningkatkan produktifitas jika hal-hal tersebut ditingkatkan. Analisis atas investasi dalam bidang pendidikan dan kesehatan menyatu pada pendekatan modal manusia. Investasi awal dilakukan, maka dapat dihasilkan suatu aliran penghasilan masa depan dari perbaikan pendidikan dan kesehatan. Pendidikan menjadi salah satu komponen vital dalam pertumbuhan dan perkembangan suatu negara. Peran ganda pendidikan, yaitu sebagai input dan output, membuat pendidikan sangat penting dalam pembangunan ekonomi. Pendidikan di negara berkembang berperan untuk membentuk sebuah kemampuan negara dalam menyerap teknologi modern dan mengembangkan kapasitas agar tercipta pertumbuhan dan pembangunan yang berkelanjutan. Dengan pendidikan potensi yang dimiliki seseorang akan dapat terarahkan dengan baik, sehingga dapat menjadikan manusia yang berdaya guna. Pendidikan pula yang menjadikan manusia lebih berpengetahuan dan memiliki kemampuan yang lebih baik.

Secara umum pendidikan sebagai human capital terbukti bahwa semakin berpendidikan seseorang maka tingkat pendapatannya semakin baik. Hal ini dimungkinkan karena orang yang berpendidikan lebih produktif bila dibandingkan dengan yang tidak berpendidikan. Produktivitas seseorang tersebut dikarenakan dimilikinya keterampilan teknis yang diperoleh dari 
pendidikan. Oleh karena itu salah satu tujuan yang harus dicapai oleh pendidikan adalah mengembangkan keterampilan hidup.

Pendidikan sebagai salah satu bentuk investasi sumber daya manusia, maka orientasinya dapat dipandang melalui:

1. Education for All (Pendidikan untuk Semua/Pendidikan Universal)

Education for all ini mulai disosialisasikan melalui Konferensi Internasional di Jomtien Thailand pada tahun 1990, yang di kita lebih dikenal dengan PUS atau pendidikan untuk semua. Deklarasi ini menegaskan bahwa setiap anak, remaja, dan semua orang dewasa mempunyai hak (Hak Asasi) untuk memperoleh keuntungan dan manfaat dari proses pendidikan yang diarahkan pada pemenuhan semua kebutuhan dasar pembelajaran (basic learning needs) setiap individu. Dari aspek ini pendidikan mengemban orientasi pada upaya mencerdaskan kehidupan bangsa sebagaimana dituangkan dalam Pembukaan Undang Undang Dasar 1945. Fungsi ini tercermin pada ketentuan pasal 31 ayat (1) bahwa "setiap warga negara berhak mendapatkan pendidikan dan pengajaran dan pemerintah mengusahakan satu sistem pendidikan nasional (ayat 2). Pasal ini merupakan landasan yang kuat bagi pemerintah untuk mengemban program pendidikan untuk semua (education for all), hal ini mengandung makna bahwa kebijakan pendidikan nasional yang ditempuh mampu merespon kondisi masyarakat yang sangat beranekaragam tanpa memandang perbedaan ras, suku bangsa, etnis, agama, sosioekonomi, dan budaya yang dianut. (Miles \& Singal, 2010).
Konfrensi dunia tentang education for all mencakup empat kelompok sasaran, meliputi; (a) pendidikan awal atau pendidikan anak usia dini, (b) universalisasi pendidikan dasar, (c) program pemberantasan buta huruf, (d) pendidikan berkelanjutan dan belajar seumur hidup. (Suryana, 2013).

2. Education for Self-help (Pendidikan menjadikan individu menolong dirinya sendiri)

Salah satu pendekatan untuk memposisikan peran pendidikan di sekolah adalah melihat peran sekolah untuk menolong individu, keluarga, masyarakat dan negara dalam menjawab permasalahan yang perlu dipecahkan. Empat pilar UNESCO tentang pembangunan pendidikan suatu bangsa menitikberatkan kepada empat utama: (1) learning to know, (2) learning to do, (3) learning to be, dan (4) learning to live together in peace and harmony. Esensi keempat pilar itu adalah bahwa pendidikan mampu menguasai ilmu pengetahuan dan teknologi, pendidikan itu juga mampu menerapkannya dalam kehidupan untuk kesejahteraan manusia, bahwa pendidikan itu merupakan pengembangan diri setinggi dan seoptimal mungkin, dan bahwa pendidikan adalah untuk keberhasilan dalam kehidupan di dunia dengan adil, tenteram dan sejahtera.(Trinova, 2013).

Pendidikan yang menghasilkan outcome seperti ini adalah pendidikan yang mampu memiliki kekuatan untuk membangun kualitas dan meningkatkan martabat suatu bangsa. Kenyataan yang masih kita hadapi adalah sebagian besar lulusan sekolah (khususnya SMU/MA) yang 
Hikmah, Vol. 18, No. 2, Juli-Desember 2021, p-ISSN: 1829-8419 e-ISSN: 2720-9040

tidak melanjutkan ke perguruan tinggi dan sebagian besar lulusan SLTP/MTs tidak melanjutkan ke SLTA. Kenyataan ini mengundang pemikiran serius, bagaimana kelanjutan masa depan mereka menolong dirinya dalam menghadapi berbagai permasalahan hidup, karena lulusan SLTP dan SMU pada dasarnya tidak dibekali kesiapan khusus (life skiils) untuk memasuki dunia kerja. Oleh karena itu konsep "life skills" di sekolah-sekolah perlu dilakukan untuk memberikan bekal bagi siswa untuk berperan secara efektif dalam kehidupan bermasyarakat, berbangsa dan bernegara.

\section{Perkembangan Pendidikan sebagai Human Capital}

Berbagai upaya untuk meningkatkan Human Capital dianggap sebagai sebuah keputusan investasi. Investasi manusia dalam membangun human capitalnya dapat dibagi menjadi tiga tahapan yaitu usia anak-anak, remaja dan dewasa, dan pada saat memasuki pasar kerja. Pada masa anak-anak, bentuk investasi human capital berupa bimbingan dari orang tua dan pengaruh lingkungan sekitar periode pertumbuhan anak, misalnya di sekolah. Sementara itu pada usia remaja dan dewasa, investasi dalam human capital biasanya diperoleh dari pendidikan formal di sekolah. Sedangkan pada periode memasuki pasar kerja, pekerja berinvestasi dalam bentuk pengalaman, on the job training, pelatihan, keterampilan, maupun program training lainnya. (Prasojo et al., 2017).

Pendidikan sebagai investasi didasarkan pada anggapan bahwa manusia merupakan suatu bentuk capital (modal) yang sangat menentukan taraf produktifitas individu maupun kelompok, yang pada gilirannya taraf produktifitasnya ini mempengaruhi taraf perolehan (earning) seseorang dan pada akhirnya berkontribusi terhadap kecepatan pertumbuhan ekonomi dan pembangunan bangsa.

Abad ke-20 sering dipuja sebagai "abad modal manusia" oleh para sarjana di Amerika Serikat, selama periode ini gerakan massa baru terhadap pendidikan menengah membuka jalan bagi transisi ke pendidikan massa yang lebih tinggi. Teknik-teknik baru dan proses pendidikan lebih lanjut dari norma sekolah dasar, yang dengan demikian menyebabkan terciptanya pendidikan formal lebih di seluruh bangsa. Kemajuan ini menghasilkan kebutuhan tenaga kerja terampil lebih yang menyebabkan upah pekerjaan yang diperlukan untuk pendidikan lebih jauh menyimpang dari upah orang yang dibutuhkan kurang. Perbedaan ini menciptakan insentif bagi individu untuk menunda memasuki pasar tenaga kerja untuk mendapatkan pendidikan yang lebih.

Para penganut teori human capital berpendapat bahwa pendidikan adalah sebagai investasi sumber daya manusia yang memberi manfaat moneter ataupun nonmoneter. Manfaat non-meneter dari pendidikan adalah diperolehnya kondisi kerja yang lebih baik, kepuasan kerja, efisiensi konsumsi, kepuasan menikmati masa tua dan manfaat hidup yang lebih lama karena peningkatan gizi dan kesehatan. Manfaat moneter adalah manfaat ekonomis yaitu berupa tambahan pendapatan seseorang yang telah menyelesaikan tingkat pendidikan tertentu dibandingkan dengan pendapatan 
lulusan pendidikan di bawahnya. (Ismail, 2015).

Pengelolaan Pendidikan sebagai Human Capital di Indonesia

Program-program utama bidang pendidikan di Indonesia adalah:

a) Program Wajib Belajar Sembilan Tahun, dengan titik berat:

1. Peningkatan partisipasi anak yang belum mendapatkan layanan pendidikan dasar.

2. Penurunan angka putus sekolah dan angka mengulang kelas, serta meningkatkan kualitas pendidikan.

3. Penyedia tambahan layanan pendidikan bagi anak-anak yang tidak dapat melanjutkan ke jenjang pendidikan menengah.

b) Program pendidikan menengah, dengan titik berat:

1. Peningkatan penyediaan layanan pendidikan menengah guna menyerap naiknya lulusan pendidikan dasar.

2. Penurunan angka putus sekolah dan angka mengulang kelas, serta meningkatkan kualitas pendidikan.

3. Penguatan pendidikan vokasi melalui sekolah/madrasah umum dan kejuruan.

c) Program pendidikan tinggi, dengan titik berat:

1. Peningkatan kualitas pendidikan dan daya saing bangsa.

2. Peningkatan otonomi dan desentralisasi pendidikan tinggi.
3. Peningkatan peluang dan kesehatan organisasi pendidikan tinggi.

d) Program peningkatan mutu pendidik dan tenaga kependidikan, dengan titik berat:

1. Peningkatan rasio pelayanan pendidik dan tenaga kependidikan terhadap peserta didik.

2. Peningkatan kualitas pendidik dan tenaga kependidikan untuk setiap jenis, jalur dan jenjang pendidikan.

3. Peningkatan kesejahteraan dan perlindungan hukum terhadap pendidik dan tenaga kependidikan.

4. Pelembagaan sistem standarisasi dan sertifikasi kompetensi pendidik dan tenaga kependidikan. (Djatola, 2021).

Pemikiran mengenai manusia sebagai pelaku utama perubahan ekonomi di suatu negara didukung oleh teori human capital. Teori human capital menunjukkan bahwa hasil dari investasi pendidikan memiliki tingkat pengembalian sosial yang jauh lebih tinggi dibandingkan investasi berupa pembangunan fisik. Teori human capital memposisikan manusia sebagai modal layaknya mesin sehingga seolah-olah manusia sama dengan mesin. Namun setelah teori ini semakin meluas, maka human capital justru bisa membantu pengambil keputusan di negara-negara yang masih berkembang untuk memfokuskan pembangunan manusia yaitu menitikberatkan pada investasi pendidikan. (Dwi Atmanti, 2005). 
Hikmah, Vol. 18, No. 2, Juli-Desember 2021, p-ISSN: 1829-8419 e-ISSN: 2720-9040

Pada praksis manajemen pendidikan modern, salah satu dari lima fungsi pendidikan adalah fungsi teknis ekonomis baik pada tataran individual maupun tataran global. Fungsi teknis ekonomis merujuk pada kontribusi pendidikan untuk perkembangan ekonomi. Misalnya, pendidikan dapat membantu siswa untuk mendapatkan pengetahuan dan keterampilan yang diperlukan untuk hidup dan berkompetisi dalam ekonomi yang kompetitif. Secara umum terbukti bahwa semakin berpendidikan seseorang, maka semakin baik tingkat pendapatannya. Hal ini dimungkinkan karena orang yang berpendidikan lebih produktif bila dibandingkan dengan yang tidak berpendidikan. (Zahro et al., 2018).

Implikasi dari pembangunan pada aspek pendidikan adalah kehidupan manusia akan semakin berkualitas. Ini tentu terkait dengan perekonomian secara umum yaitu semakin tinggi kualitas hidup suatu bangsa maka akan semakin tinggi tingkat pertumbuhan dan kesejahteraan masyarakat. Semakin tingginya investasi sumber daya manusia akan berimplikasi pada peningkatan pertumbuhan ekonomi nasional.

Namun sayangnya, negara berkembang memiliki berbagai problem dalam memfokuskan anggaran untuk pendidikan. Di Indonesia sendiri, perhatian besar yang memiliki landasan hukum yang lebih jelas terjadi setelah adanya perubahan keempat Undang-Undang Dasar Negara Republik Indonesia Tahun 1945, yaitu pada pasal 31 ayat (4) yang isinya: Negara memprioritaskan anggaran pendidikan sekurang-kurangnya dua puluh persen dari anggaran pendapatan dan belanja negara serta dari anggaran pendapatan dan belanja daerah untuk memenuhi kebutuhan penyelenggaraan pendidikan nasional.

Semenjak munculnya angka dua puluh persen untuk anggaran pendidikan dalam UUD Negara RI 1945, maka perhatian terhadap pendidikan telah diimplementasikan dalam anggaran pendapatan dan belanja negara dengan mulai mempertinggi persentase anggaran, dan hingga saat ini persentase terbesar dalam anggaran pendapatan dan belanja negara adalah untuk sektor pendidikan.

Kualitas SDM Indonesia masih jauh tertinggal dibandingkan dengan negaranegara lain, hal ini dapat diketahui dari:

1. Indeks Pembangunan Manusia (IPM) urutan 112 dari 175 negara.

2. Indeks Pembangunan Gender (Gender-related Development Index, GDI) Indonesia berada di urutan 91 dari 144 negara.

3. Indeks Pencapaian Teknologi (IPT) Indonesia berada pada urutan ke 60 dari 72 negara. (Muhardi, 2005).

Dalam teori human capital, individu yang menjalani pendidikan akan memberikan tingkat pengembalian sosial. Berdasarkan kerangka pemikiran ini, maka seharusnya individu yang berada pada jajaran pengambil keputusan (di berbagai level) dan termasuk dalam memberikan layanan publik mampu membuktikan tingkat pengembalian sosial mereka dalam bentuk munculnya berbagai kebijakan yang mengangkat derajat hidup rakyat dan memberikan layanan yang baik kepada publik. 
Pemerintah selain mendirikan lembaga pendidikan formal, harus mendirikan suatu lembaga penyaluran kerja, yang didalamnya menyangkut tentang pelatihan pekerjaan dan pengarahan terhadap siswa mendapat pekerjaan dengan mudah dan cepat. Namun terlepas dari hal tersebut pemerintah juga di tuntut untuk mengimbanginya dengan menciptakan lapangan pekerjaan yang lebih banyak, sehingga tidak terjadi peledakan pengangguran yang semakin banyak. Selain itu untuk menciptakan lapangan pekerjaan, modal merupakan hal yang terpenting, maka dari itu di Indonesia ini sebaiknya peminjaman modal di permudah sehingga para pencipta lapangan pekerjaan menjadi lebih mudah dan efisien.

\section{Pandangan Islam terhadap Human Capital}

Islam sebagai sebuah jalan hidup, mengajarkan dan mengatur bagaimana menempatkan sumber daya manusia pada sebuah syirkah (perusahaan). Islam sangat peduli terhadap hukum perlindungan hakhak dan kewajiban mutualistik antara pekerja dengan yang mempekerjakan.

Etika kerja dalam Islam mengharuskan, bahwa gaji dan bayaran serta spesifikasi dari sebuah pekerjaan yang akan dikerjakan harus jelas dan telah disetujui pada saat adanya kesepakatan awal, dan pembayaran telah dilakukan pada saat pekerjaan itu telah selesai tanpa ada sedikitpun penundaan dan pengurangan. Para pekerja juga mempunyai kewajiban untuk mengerjakan pekerjaannya secara benar, effektif, dan effisien. (Ahmad \& Lubis, 2015).

Alquran mengakui adanya perbedaan upah diantara pekerja atas dasar kualitas dan kuantitas kerja yang dilakukan sebagaimana yang dikemukakan dalam surah al-Ahqaaf ayat 19, surah al-Najm ayat 39-41. Sungguh sangat menarik apa yang ada dalam Al Quran yang tidak membedakan perempuan dengan laki-laki dalam tataran dan posisi yang sama untuk masalah kerja dan upah yang mereka terima, sebagaimana yang terungkap dalam Surah Ali' Imran ayat 195.

Islam juga menganjurkan, untuk melakukan tugas-tugas dan pekerjaan tanpa ada penyelewelengan dan kelalaian, dan bekerja secara efisien dan penuh kompetensi. Ketekunan dan ketabahan dalam bekerja dianggap sebagai sesuatu yang mempunyai nilai terhormat. Suatu pekerjaan kecil yang dilakukan secara konstan dan professional lebih baik dari sebuah pekerjaan besar yang dilakukan dengan cara musiman dan tidak professional.(Nata, 2017).

Hal ini sesuai dengan Sabda Rasullulah yang berbunyi "Sebaik-baiknya pekerjaan adalah yang dilakukan penuh ketekunan walaupun sedikit demi sedikit." (H.R. Tirmidzi). Kompetensi dan kejujuran adalah dua sifat yang membuat seseorang dianggap sebagai pekerja unggulan sebagaimana yang dinyatakan dalam Surah Al Qashash ayat 26.

Standar Alquran untuk kepatutan sebuah pekerjaan adalah berdasarkan pada keahlian dan kompetensi seseorang dalam bidangnya. Ini merupakan hal penting, karena tanpa adanya kompentensi dan kejujuran, maka bisa dipastikan tidak akan 
Hikmah, Vol. 18, No. 2, Juli-Desember 2021, p-ISSN: 1829-8419 e-ISSN: 2720-9040

lahir efisiensi dari seseorang. Oleh karena itu, merupakan kewajiban bagi manajemen sebuah organisasi (perusahaan) untuk menempatkan seseorang sesuai dengan kompetensinya.

Berdasarkan ayat-ayat di atas, dapat disimpulkan, bahwa Islam mengajarkan sumber daya manusia dalam sebuah perusahaan merupakan salah satu modal bukan sebagai pembawa kerugian. Dengan demikian, penanganan sumber daya manusia sebagai human capital, bukanlah sesuatu yang baru dalam aktivitas ekonomi Islami.

Human Capital atau faktor manusia harus ditingkatkan untuk memajukan peradaban Islam. Human capital adalah salah satu kunci untuk memajukan suatu peradaban, termasuk peradaban Islam. Majunya peradaban Islam di masa lampau antara lain karena keberhasilan umat Islam dalam mengintegrasikan secara harmonis antara ilmu pengetahuan rasionalitas-analitis dan ilmu yang bersifat spiritual-moralis. (Lubis, 2016).

Peradaban Islam yang berjaya pada abad pertengahan adalah peradaban yang pertama kali melakukan proses internasionalisasi ilmu pengetahuan yang membuka pula ke arah globalisasi awal. Islam juga yang memperkenalkan berbagai konsep yang berpengaruh pada masa selanjutnya seperti sistem pemerintahan yang baik yang terdapat dalam Piagam Madinah dalam masa Rasulullah SAW. Kemunduran perbedaan Islam disebabkan oleh perpecahan dan rusaknya Sumber Daya Manusia (SDM) baik secara intelektual maupun moral. (Akhir \& Sabjan, 2014).
Umat Islam di Indonesia juga tertinggal dalam hal inovasi yang merupakan salah satu hal yang dapat mencerminkan daya tahan suatu bangsa dalam menghadapi beragam tantangan di era globalisasi kini. Untuk itu, memajukan peradaban Islam dapat dimulai dengan memajukan pendidikan dan meneruskan kembali tradisi kelimuan yang pernah ada di dunia Islam agar dapat menciptakan manusia yang berkarakter akhlak mulia dan berpikir cerdas, inovatif, kreatif, dan responsif. (Lubis \& Nasution, 2017).

\section{SIMPULAN}

Pendidikan sangat berpengaruh kepada ekonomi suatu bangsa. Pendidikan bukan hanya dapat menjadikan manusia yang berpengetahuan, berpendidikan, dan mengetahui teknologi saja, namun pendidikan dapat dijadikan sarana sebagai penunjang pertumbuhan ekonomi. Karena dengan pendidikan manusia membuat inovasi-inovasi baru yang menunjang ekonomi sesuai dengan perkembangan zaman. Alasan mengapa pendidikan sebagai Human Capital atau Human Investasi adalah karena Pendidikan merupakan investasi yang paling penting dalam modal manusia untuk menjawab tantangan global pada saat ini. Banyak penelitian telah menunjukkan bahwa sekolah tinggi dan pendidikan tinggi di Indonesia sangat meningkatkan pendapatan seseorang. Seseorang dengan pendidikan lebih cenderung memiliki IQ yang lebih tinggi dan lebih baik berpendidikan. Bukti serupa yang mencakup bertahun-tahun sekarang tersedia dari lebih dari seratus negara dengan budaya yang berbeda dan 
sistem ekonomi. Pendapatan dari lebih banyak orang berpendidikan hampir selalu jauh di atas rata-rata, walaupun keuntungan umumnya lebih besar di negara-negara berkembang. Tentu saja, pendidikan formal bukan satu-satunya cara untuk berinvestasi dalam modal manusia. Pekerja juga belajar dan dilatih di luar sekolah, terutama pada pekerjaan. Bahkan lulusan perguruan tinggi tidak sepenuhnya siap menghadapi pasar tenaga kerja ketika mereka meninggalkan sekolah dan harus dipasang ke pekerjaan mereka melalui program pelatihan formal dan informal. Oleh karena itu keahlian dan kecakapan seseorang dalam menghadapi persaingan tenaga kerja sangat dipengaruhi oleh seberapa tinggi dan luasnya pendidikan yang dimiliki masing-masing individu. Maka dari itu diperlukannya usaha-usaha dan program-program untuk menciptakan sumber daya manusia yang unggul dan bermutu tinggi untuk menghadapi persaingan internasional karena dunia kerja sangat menuntut untuk memperoleh sumber daya manusia yang bervariasi tinggi.

\section{DAFTAR PUSTAKA}

Abidin, A. A. (2017). Manajemen pembiayaan pendidikan tinggi dalam upaya peningkatan mutu (Studi kasus pada perguruan tinggi swasta menengah di Surabaya). Jurnal Penjaminan Mutu, 3(1), 87-99.

Ahmad, S. F., \& Lubis, M. A. (2015). Islam Hadhari dalam Pendidikan Pembangunan Modal Insan di Malaysia: Satu Analisa Epistimologi (Islam Hadhari in the Education of Human Capital in Malaysia: An Epistemological Analysis). Jurnal Hadhari: An International Journal, 7(1), 1-18.
Akdon, Kurniady, D. A., \& Darmawan, D. (2015). Manajemen Pembiayaan Pendidikan (P. Laatifah (ed.)). Remaja Rosdakarya.

Akhir, N. S. M., \& Sabjan, M. A. (2014). Pembangunan Modal Insan dari Perspektif Kerohanian Agama: Islam Sebagai Fokus (Human Capital Development Based on The Aspect of Religious Spirituality: The Islamic Perspective). Journal of Human Capital Development (JHCD), 7(1), 33-48.

Djatola, H. (2021). Peran Human Capital Sebagai Sumber Strategi dalam Peningkatan Mutu Pendidikan di Organisasi Pendidikan Tinggi: The Role of Human Capital as A Source of Strategy In Improving The Quality of Education In The Organizationshigh Education. Jurnal Sosial Humaniora, 12(2), 139-153.

Dwi Atmanti, H. (2005). Investasi sumber daya manusia melalui pendidikan. Jurnal Dinamika Pembangunan (JDP), 2(1), 30-39.

Ferdi, W. P. (2013). Pembiayaan pendidikan: Suatu kajian teoritis. Jurnal Pendidikan Dan Kebudayaan, 19(4), 565-578. http://jurnaldikbud.kemdikbud.go.id/ind ex.php/jpnk/article/view/310

Ismail, S. H. (2015). Pembangunan Insan dalam Falsafah Pendidikan Kebangsaan (Human Development in National Education Philosophy). Journal of Human Capital Development (JHCD), 8(2), 83-100.

Lubis, R. R. (2016). Kompetensi Kepribadian Guru Dalam Persfektif Islam (Studi Pemikiran Nasih 'Ulwān Dalam Kitab Tarbiyatul Aulād). Tazkiya, 5(2), 1-13. http://jurnaltarbiyah.uinsu.ac.id/index.p hp/tazkiya/article/viewFile/83/67

Lubis, R. R., \& Nasution, M. H. (2017). Implementasi Pendidikan Karakter di Madrasah. JIP (Jurnal Ilmiah PGMI), 
Hikmah, Vol. 18, No. 2, Juli-Desember 2021， p-ISSN: 1829-8419 e-ISSN: 2720-9040

$3(1), 15-32$.

Mesiono, M., \& Lubis, R. R. (2021). Manajemen Finansial Pendidikan di Indonesia (Diskursus Sistem Perpajakan pada Institusi Pendidikan). Al-Fikru: Jurnal Ilmiah, 15(1), 14-27. https://doi.org/10.51672/alfikru.v15i1.2 1

Miles, S., \& Singal, N. (2010). The Education for All and inclusive education debate: conflict, contradiction or opportunity? International Journal of Inclusive Education, 14(1), 1-15.

Muhardi. (2005). Kontribusi Pendidikan Dalam Meningkatkan Kualitas Bangsa Indonesia. Journal Unisba.

Nata, A. (2017). Menjadikan Tarbiyah Islamiyah Sebagai Modal Meraih Pendidikan Masa Depan. Al-Fikra: Jurnal Ilmiah Keislaman, 8(2), 223245.

Prasojo, L. D., Mukminin, A., \& Mahmudah, F. N. (2017). Manajemen strategi human capital dalam pendidikan. Yogyakarta: UNY Press, Edisi, 1(3), 16-24.

Prayoga, A., \& Risnandi, A. (2019). Manajemen Pembiayaan Pendidikandi Madrasah Aliyah Darussalam Sumedang. Cakrawala: Jurnal Manajemen Pendidikan Islam Dan Studi Sosial, 3(2), 117-131.

Romadhon, A. (2016). Kemandirian Finansial Lembaga Pendidikan Melalui Entrepreneurship Dan Partnership. Jurnal Manajemen Pendidikan, 7(1), 1197-1204.

https://doi.org/10.21009/jmp.07101

Suryana, D. (2013). Profesionalisme Guru Pendidikan Anak Usia Dini Berbasis Peraturan Menteri No. 58 Tahun 2009. Pedagogi: Jurnal Ilmiah Ilmu Pendidikan, 13(2), 53-61.

Trinova, Z. (2013). Pembelajaran berbasis student-centered learning pada materi pendidikan agama islam. Al-Ta Lim Journal, 20(1), 324-335.

Zahro, A. M., Sobri, A. Y., \& Nurabadi, A. (2018). Kepemimpinan perubahan kepala sekolah dalam peningkatan mutu pendidikan. JAMP: Jurnal Administrasi Dan Manajemen Pendidikan, 1(3), 358363.

http://dx.doi.org/10.17977/um027v1i32 018 p3358 